\title{
Design and Test of a Topless Shrimp Trawl to Reduce Pelagic Fish Bycatch in the Gulf of Maine Pink Shrimp Fishery
}

\author{
Pingguo He \\ Ocean Process Analysis Laboratory of Institute for the Study of Earth, \\ Oceans and Space and New Hampshire Sea Grant, \\ University of New Hampshire, 142 Morse Hall, Durham, NH, USA 03824 \\ E-mail: phe@ceunh.unh.edu \\ David Goethel \\ F/V “Ellen Diane”, 23 Ridgeview Terrace, Hampton, NH, USA 03842 \\ and \\ Tracey Smith \\ Ocean Process Analysis Laboratory of Institute for the Study of Earth, \\ Oceans and Space, University of New Hampshire, \\ 142 Morse Hall, Durham, NH, USA 03824
}

He, P., D. Goethel, and T. Smith. 2007. Design and test of a topless shrimp trawl to reduce pelagic fish bycatch in the Gulf of Maine pink shrimp fishery. J. Northw. Atl. Fish. Sci., 38: 13-21. doi:10.2960/J.v38.m591

\begin{abstract}
A new innovative topless shrimp trawl was designed and tested in the flume tank, and at sea to evaluate its potential of reducing finfish bycatch in the pink shrimp fishery in the Gulf of Maine. The trawl design removed the square and the top part of the section after the square (first belly section), to become "topless". A five-day sea trial was carried out using the alternating tow method to compare the topless trawl and a commercial (control) trawl. The target species was the pink shrimp (Pandalus borealis) and the major bycatch species was Atlantic herring (Clupea harengus) that formed $90.6 \%$ of all bycatch by weight. Comparative fishing indicated that the topless trawl reduced bycatch of Atlantic herring by an average of $86.6 \%$, and at the same time produced a modest increase of $13.5 \%$ in the catch of the pink shrimp. There was some increase in the bycatch of flounders, particularly American plaice and winter flounder, though overall amount of flounder bycatch was less than 3\% of the total catch. The reduction of Atlantic herring was most likely due to the fish escaping over the headline where the top panel was removed. The increased bycatch of flounders (and increased catch of shrimp) might have resulted from a wider wingend spread and subtle differences in the footgear between the topless and commercial trawls. The substantial reduction of Atlantic herring, the major bycatch species, without a reduction of the target shrimp species proved the concept of the topless trawl and may have a profound impact on other shrimp trawl fisheries around the world.
\end{abstract}

Keywords: bycatch reduction, Clupea harengus, herring, Pandalus borealis, shrimp, trawl

\section{Introduction}

Before 1992, large quantities of juvenile groundfish were discarded by small mesh shrimp trawlers in the Gulf of Maine (Howell and Langan, 1992). The use of the Nordmore grid became mandatory in 1992 in the fishery and has reduced finfish bycatch tremendously (Kenny et al., 1992; Clark et al., 2000). However, a Nordmore grid cannot reduce small fish that can pass through the $25 \mathrm{~mm}$ (1") spacing between the grid bars (Clark et al., 2000). Small fish such as Atlantic herring, silver hake, juvenile cod, haddock, red hake and flounders are often caught as bycatch in various quantities. In a separate shrimp trawl project carried out during the 2002 and 2003 shrimp seasons, an average of $13 \mathrm{~kg}$ of bycatch was caught for every $100 \mathrm{~kg}$ of shrimp (He and Littlefield, MS 2006), 
though the majority of bycatch were less valuable species such as silver hake and red hake. In another project carried out in April 2004, the bycatch of silver hake was as much as $400 \mathrm{~kg}$ per hour tow, which was three times more than the shrimp catch (He et al., MS 2005). Thus there is potential for reducing finfish bycatch, which will conserve finfish stocks, as well as reduce sorting time on deck and improve shrimp quality.

Existing Pandalus shrimp trawls follow traditional groundfish trawl designs with an overhung panel, called the square or roof, whose purpose is to prevent finfish from escaping over the headline. In shrimp trawls, the opposite is desired, i.e. the majority of fish should be allowed to escape before entering the trawl. A trawl without a square, targeting Norway lobster (Nephrops norveigicus), was tested in the English Channel and proved successful in reducing the bycatch of haddock, whiting and other finfish species (Arkley and Dunlin, MS 2003; Revill et al., 2006).

Recent findings by Valdemarsen (MS 2005) indicated that shrimp roll along bottom belly netting of a trawl when passing towards the codend. He found that the majority of shrimp were not more than $10 \mathrm{~cm}$ from the netting. This finding suggests that most of the top netting of a shrimp trawl may be removed without losing much shrimp. A shrimp trawl without top netting would thus be able to retain the majority of shrimp entering into the mouth of a trawl while releasing finfish species. The new trawl may be called the "topless" shrimp trawl, similar to the topless flounder trawl tested by Pol and his colleagues (Pol et al., MS 2003). Fish escapement during the early stages of the fishing process will help reduce stress, injury and associated unaccounted fishing mortality, and contribute to a healthier status of these fish stocks.

\section{Materials and Methods}

\section{Gear Design and Flume Tank Tests}

The topless trawl has no square and no top netting immediately behind the square. The wings of the trawl are longer than a traditional trawl to increase horizontal spread and to compensate for possible loss of shrimp due to reduced headline height. The lower belly of the trawl rises sharply so that the fishing circle at the middle of the headline is small in order to facilitate easy escape of finfish over the headline. The net plan of the topless trawl is shown in Fig. 1, and a 1:5 scale model built from the net plan and as seen in the Newfoundland flume tank is shown in Fig. 2. The topless trawl has a headline length of $31.91 \mathrm{~m}$ and fishing line $24.02 \mathrm{~m}$ (Table 1). The groundgear length for the trawl is $27.68 \mathrm{~m}$.

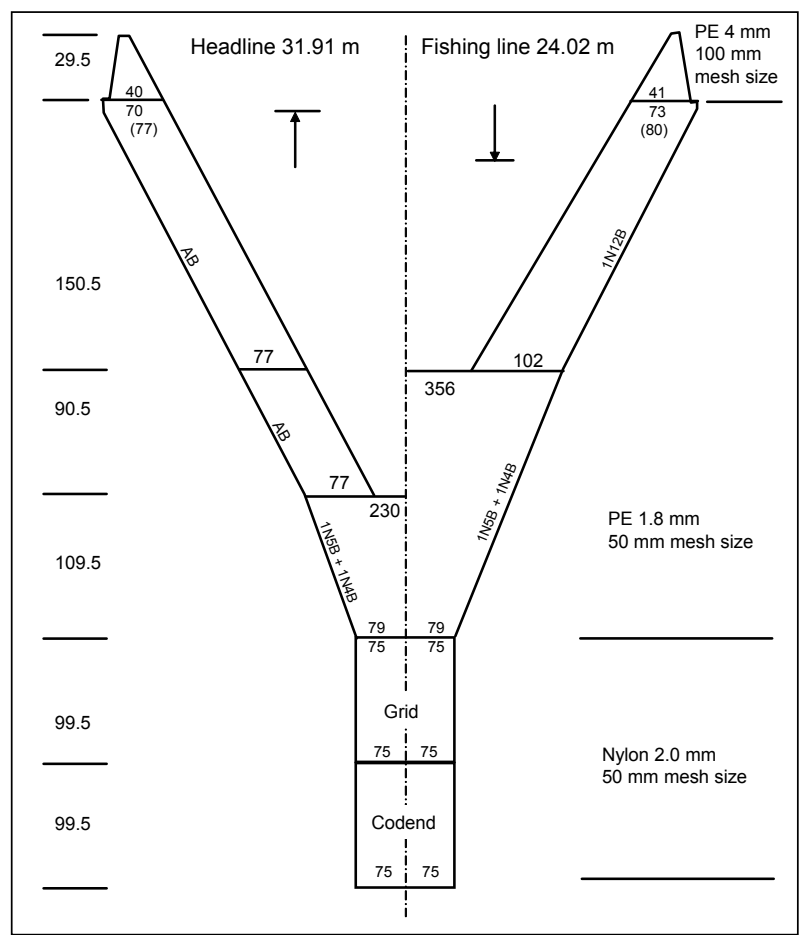

Fig. 1. Net plan of the topless trawl tested in the Gulf of Maine pink shrimp fishery in 2006. The numbers on the left hand side are number of meshes in length for each section. The numbers inside the plan indicate number of mesh in width.

Flume tank tests were carried out at the Center for Sustainable Aquatic Resource of the Memorial University of Newfoundland in St. John's, Canada. The measurements made at the flume tank of the model topless trawl and scaled to full size terms are shown in Table 2. During comparative fishing two additional floats were added at the quarter.

\section{Sea Trials}

F/V "Ellen Diane", a 13.7 m (45') inshore shrimp trawler based in Hampton Harbor, New Hampshire, was used for comparative fishing trials. Experimental fishing started in early February 2006 on shrimp fishing grounds off New Hampshire. The tow duration was half an hour and the towing speed was 2.4 knots. Commercial tow durations range from one to four hours depending on catch rates. The choice of shorter tow duration during the experiment was due to the relative high catch rates. Water depth was 70-81 m with a warp length of $229 \mathrm{~m}$ during all tows.

A 5-day comparative fishing trial was carried out using the alternating tow method with the experimental 


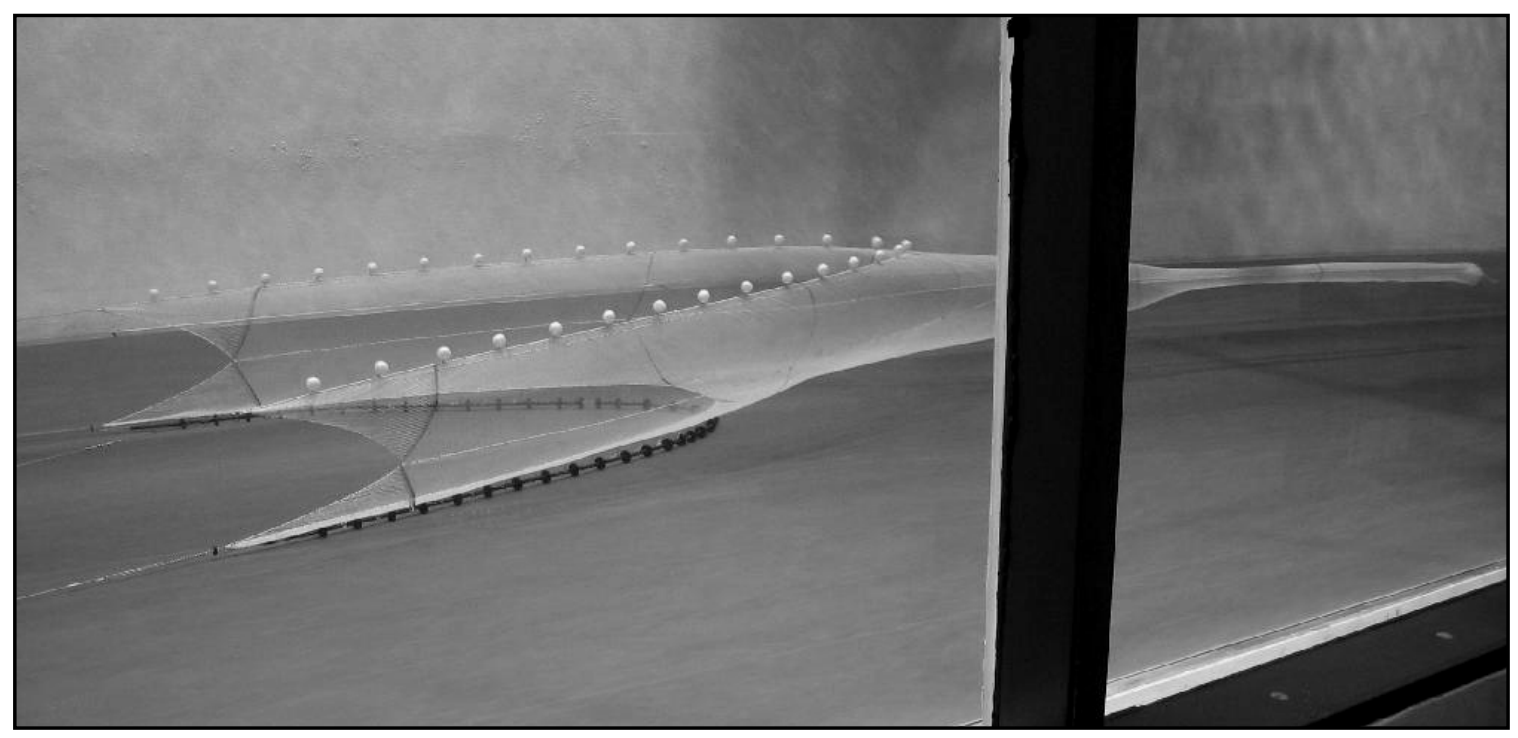

Fig. 2. A 1:5 scale-model of the topless trawl as seen in the flume tank at the Memorial University of Newfoundland in Canada.

TABLE 1. Comparison of geometry of the experimental topless trawl and the control commercial trawl based on measurements made at sea ${ }^{1}$ and estimated using tank and at-sea measurements $^{2}$.

\begin{tabular}{|c|c|c|}
\hline Parameters & Topless trawl & Commercial trawl \\
\hline Headline length $^{1}(\mathrm{~m})$ & 31.91 & 15.88 \\
\hline Fishing line length $^{1}(\mathrm{~m})$ & 24.02 & 21.22 \\
\hline Door spread $^{1}(\mathrm{~m})$ & 29.74 & 29.74 \\
\hline Headline height ${ }^{1}(\mathrm{~m})$ & 2.50 & 2.46 \\
\hline Upper wingend spread ${ }^{1}(\mathrm{~m})$ & 16.62 & 10.68 \\
\hline Lower wingend spread ${ }^{2}(\mathrm{~m})$ & 14.09 & 12.28 \\
\hline Mean wingend spread ${ }^{2}(\mathrm{~m})$ & 15.35 & 11.48 \\
\hline Lower bridle angle ${ }^{2}\left(^{\circ}\right)$ & 16.7 & 18.7 \\
\hline
\end{tabular}

topless trawl and a control commercial trawl. We were testing the null hypothesis: there is no difference in catch amount and catch composition between the topless trawl and the commercial trawl. The control net was a commercial shrimp trawl used by the vessel during commercial fishing with headline length of $15.88 \mathrm{~m}$ and footgear length of $21.22 \mathrm{~m}$ (Fig. 3). Both nets used 8 " rockhopper footgear with a drop chain made of 7 links of 5/16" long link chain. The alternating tows followed a CEEC and ECCE sequence, where E denotes the experimental topless trawl and $\mathrm{C}$ denotes the control commercial trawl. Four tows per day were completed at similar fishing locations, constituting two pairs of data. During ten pairs of tows, the exact same specifications of the Nordmore grid and the codend were used for both topless and commercial trawls. The difference between the topless trawl and the commercial trawl are in the net itself, not the codend or grid. The Nordmore grid was made of stainless steel, and measured $91 \mathrm{~cm}\left(36^{\prime \prime}\right)$ long by $74 \mathrm{~cm}$ (29") wide. The grid spacing was $25.4 \mathrm{~mm}(1 ")$, the maximum legal spacing in the fishery. The grid was installed at a $50^{\circ}$ angle. The codend was made of $50 \mathrm{~mm}$ mesh size nylon material, 99.5 meshes long and 150 meshes on the round.

Headline height and upper wingend spread were monitored by the NetMind acoustic gear monitoring sys- 
TABLE 2. Geometry and force measure of the topless trawl from flume tanks tests. Bridle length $27.45 \mathrm{~m}$. All in full scale terms. UW - upper wing, LW - lower wing, WE - wingend, HL 1 - headline opening, HL 2 - headline height (from seabed), Stbd - starboard.

\begin{tabular}{|c|c|c|c|c|c|c|c|c|c|c|}
\hline \multirow{2}{*}{$\begin{array}{l}\text { Towing } \\
\text { speed } \\
\text { (knots) }\end{array}$} & \multicolumn{3}{|c|}{ Horizontal spread (m) } & \multicolumn{3}{|c|}{ Vertical height (m) } & \multicolumn{3}{|c|}{ Forces $(\mathrm{N})$} & \multirow{2}{*}{$\begin{array}{c}\text { Bridle angle } \\
\left({ }^{\circ}\right)\end{array}$} \\
\hline & Door & UW & LW & WE & HL 1 & HL 2 & Port & Stbd & Total & \\
\hline 2.0 & 26.2 & 12.9 & 11.0 & 2.4 & 2.4 & 3.2 & 0.453 & 0.476 & 0.929 & 14 \\
\hline 2.2 & 26.5 & 12.9 & 11.2 & 2.3 & 2.2 & 3.0 & 0.510 & 0.538 & 1.048 & 14 \\
\hline 2.4 & 27.2 & 13.3 & 11.3 & 2.2 & 2.1 & 2.8 & 0.587 & 0.624 & 1.211 & 15 \\
\hline 2.6 & 27.8 & 13.3 & 11.5 & 2.2 & 2.0 & 2.7 & 0.661 & 0.688 & 1.349 & 15 \\
\hline 2.8 & 28.4 & 13.5 & 11.4 & 2.1 & 1.9 & 2.5 & 0.756 & 0.791 & 1.547 & 16 \\
\hline
\end{tabular}

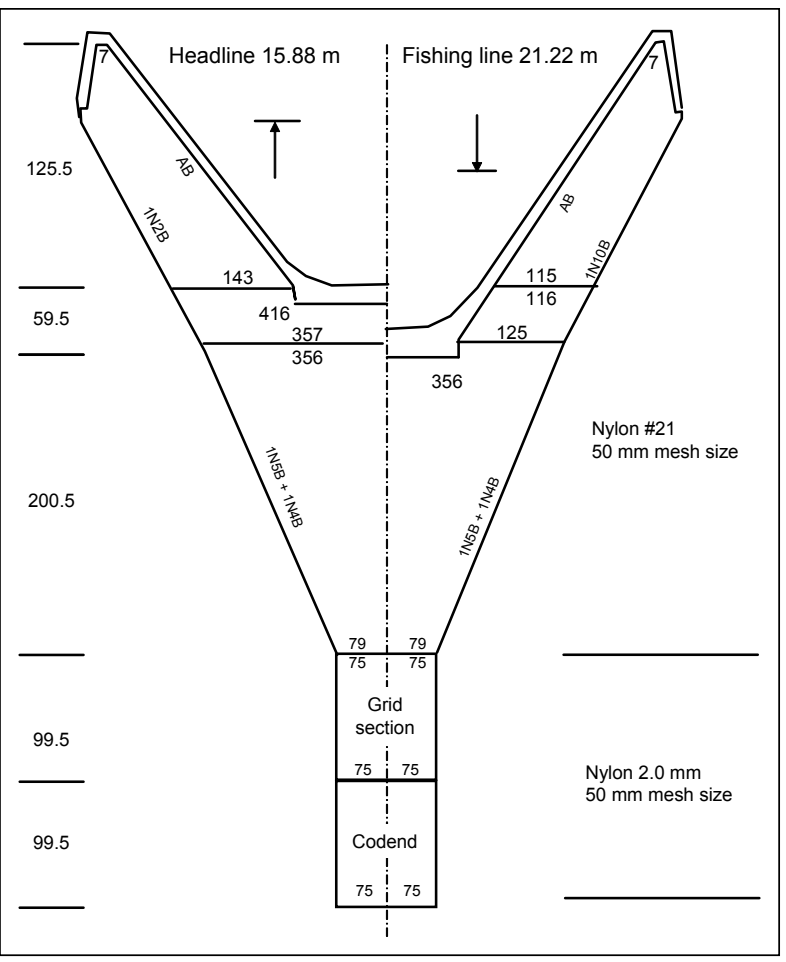

Fig. 3. Net plan of the commercial trawl used as control during the comparative fishing trial in the Gulf of Maine pink shrimp fishery in 2006. The numbers on the left hand side are number of meshes in length for each section. The numbers inside the plan indicate number of mesh in width.

tem (Northstar Technical Inc., St. John's, Newfoundland, Canada). Tow tracks were recorded by the Nobeltec mapping and plotting system to insure that comparative tows were conducted adjacent to one another and over similar bottom conditions.

\section{Data Collection and Analysis}

The catch of shrimp and finfish species was sorted and measured after each tow. Bycatch species are listed in Table 3. The shrimp catch was weighed to the nearest $\mathrm{kg}$. Controlled groundfish bycatch species (including cod, haddock, American plaice, winter flounder, witch flounder, and yellowtail flounder), other groundfish (silver hake, red hake, redfish, and butterfish) and pelagic species (mainly Atlantic herring and blueback herring), were individually measured to the nearest centimeter, and the total amount for each species was weighed to the nearest $0.05 \mathrm{~kg}$. Weighed sub-samples of about $1 \mathrm{~kg}$ were taken when a large amount of a bycatch species was caught. Other bycatch of 'trash' species were weighed and counted. A $1 \mathrm{~kg}$ shrimp sample from each tow was kept for carapace length measurement at the laboratory. Carapace lengths were measured to the nearest $\mathrm{mm}$. A portion of the shrimp sampled was individually weighed to determine the length-weight relationship.

Comparative fishing data were analyzed using paired $t$-tests to determine differences in catch rates of shrimp and bycatch species (kg/tow). Difference in the size distribution of shrimp and bycatch species from the two nets was analyzed using the two-sample Kolmogrov-Smirnov (K-S) test. The bycatch of cod, haddock, yellowtail flounder, witch flounder, red hake and redfish was negligible at the time of sea trials and was not analyzed. Bycatch of Atlantic herring, blueback herring, silver hake, American plaice and winter flounder are reported.

\section{Results}

\section{Gear Performance, Handling and Operation}

There was no problem in handling the topless trawl with the existing deck machinery onboard $\mathrm{F} / \mathrm{V}$ "Ellen 
TABLE 3. Bycatch species caught during the shrimp trawl experiment.

\begin{tabular}{ll}
\hline \hline Atlantic cod & Gadus morhua \\
haddock & Melanogrammus aeglefinus \\
yellowtail flounder & Limanda ferruginea \\
American plaice & Hippoglossoides platessoides \\
witch flounder & Glyptocephalus cynoglossus \\
winter flounder & Pseudopleuronectes americanus \\
Atlantic herring & Clupea harengus \\
blueback herring & Alosa aestivalis \\
silver hake & Merluccius bilinearis \\
red hake & Urophycis chuss \\
redfish & Sebastes fasciatus \\
butterfish & Peprilus triacanthus \\
fourspot flounder & Paralichthys oblongus \\
longhorn scuplin & Myoxocephalus octodecempinosus \\
wrymouth & Cryptacanthpdes maculatus \\
\hline
\end{tabular}

Diane". The power needed to tow the topless trawl was similar to that required for the commercial trawl as indicated by engine revolution per minute (RPM). The average RPM was 1178 for the topless net and was 1155 for the control net. The topless trawl came up clean, indicating that it was not digging into the seabed too hard. The topless trawl seemed practical in terms of operation and handling.

For both nets, the door spread was about $29.7 \mathrm{~m}$ when fishing at a depth of around $75 \mathrm{~m}$ with a bridle length of $27.5 \mathrm{~m}$ (Table 1). At this door spread, the upper wingend and lower wingend spread of the new topless net was about $16.62 \mathrm{~m}$ and $14.09 \mathrm{~m}$, with its headline height at $2.5 \mathrm{~m}$ when towed at 2.4 knots. The upper wingend and lower wingend spread for the commercial net was about $10.68 \mathrm{~m}$ and $12.28 \mathrm{~m}$, and headline height was $2.46 \mathrm{~m}$ (Table 1).

\section{Shrimp Catch}

There was an increase in the shrimp catch using the topless trawl when compared with the commercial trawl. The catch rate ranged from 55-136 kg per half hour tow. The average catch for 10 tows using the topless trawl in the comparative fishing period was $92 \mathrm{~kg}$ per tow with a standard error (SE) of $2.14 \mathrm{~kg}$ compared with $81 \mathrm{~kg}$ per tow $(\mathrm{SE}=2.18 \mathrm{~kg}$ ) for the commercial trawl, giving an average increase of $13.6 \%$ in the shrimp catch. The topless trawl outfished the commercial trawl in nine out of ten pairs (Fig. 4). The difference is statistically significant

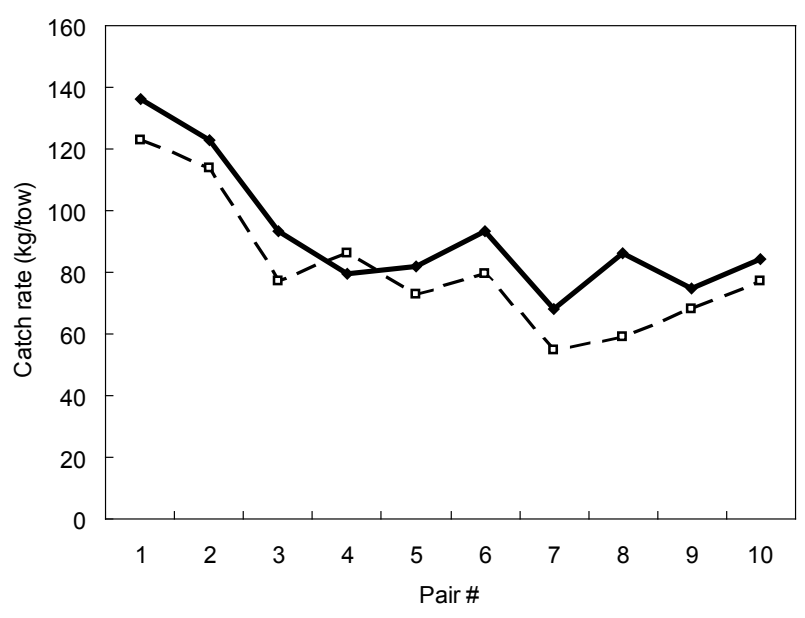

Fig. 4. Catch rates (kg/tow) of pink shrimp caught by the topless (—-) and commercial (- - - -) trawls during the 10 pairs of tows.

(paired $t$-test, $t=4.00$, d.f $.=9, p<0.01$ ) and the null hypothesis was thus rejected.

Shrimps caught in the topless trawl were slightly larger. On average, the count per $\mathrm{kg}$ was 133.6 for the topless trawl and 141.3 for the commercial trawl. Comparisons of length distribution also indicate relatively more large shrimp in the topless trawl. The two-sample Kolmogrov-Smirnov test indicates that the difference is statistically different $(Z=1.734, P=0.005)$.

\section{Finfish Bycatch}

The major finfish bycatch species was Atlantic herring. Other bycatch species include blueback herring, silver hake, American plaice, and winter flounder. Very few cod, haddock, witch flounder and yellowtail founder were caught as bycatch during the fishing period.

For the commercial trawl, shrimp accounted for $69.5 \%$ of the total catch (shrimp and bycatch combined), while bycatch accounted for $30.5 \%$, with Atlantic herring accounting for $26.3 \%$ of the total catch (Fig. 5A). For the topless trawl, shrimp represented $90.6 \%$ of the catch while Atlantic herring only accounted for $4.1 \%$ of the total catch (Fig. 5B). The topless trawl was much "cleaner" and required less labor to sort the catch.

The amount of Atlantic herring bycatch during the 10 pairs of tows is plotted in Fig. 6. Average Atlantic herring bycatch was $4.1 \mathrm{~kg}$ per tow $(\mathrm{SE}=0.45 \mathrm{~kg}$ ) while the control net caught an average of $30.7 \mathrm{~kg}$ of Atlantic herring per tow $(\mathrm{SE}=1.85 \mathrm{~kg})$. Paired analysis indicated that the experimental topless net caught significantly less 


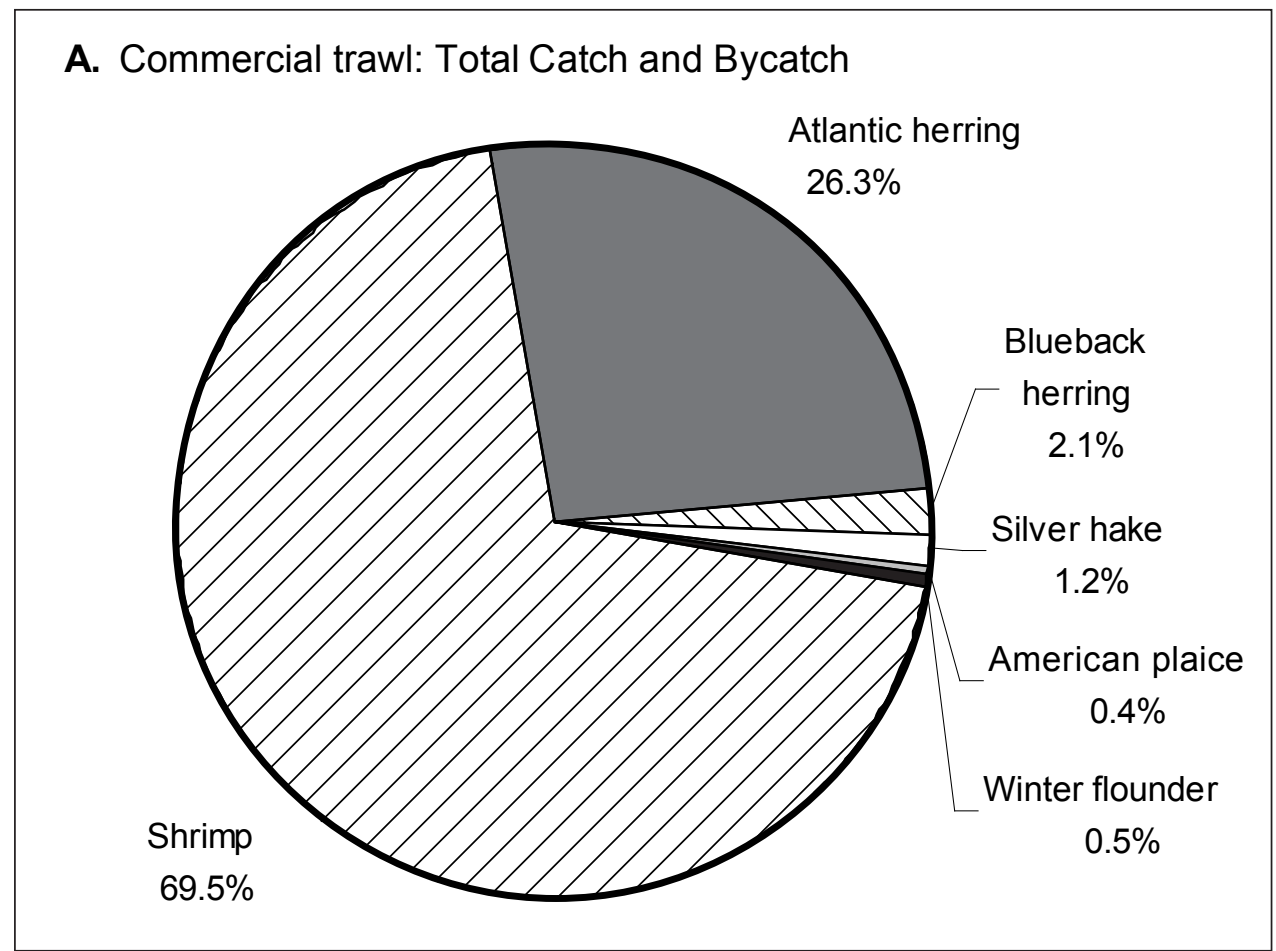

B. Topless trawl: Total Catch and Bycatch

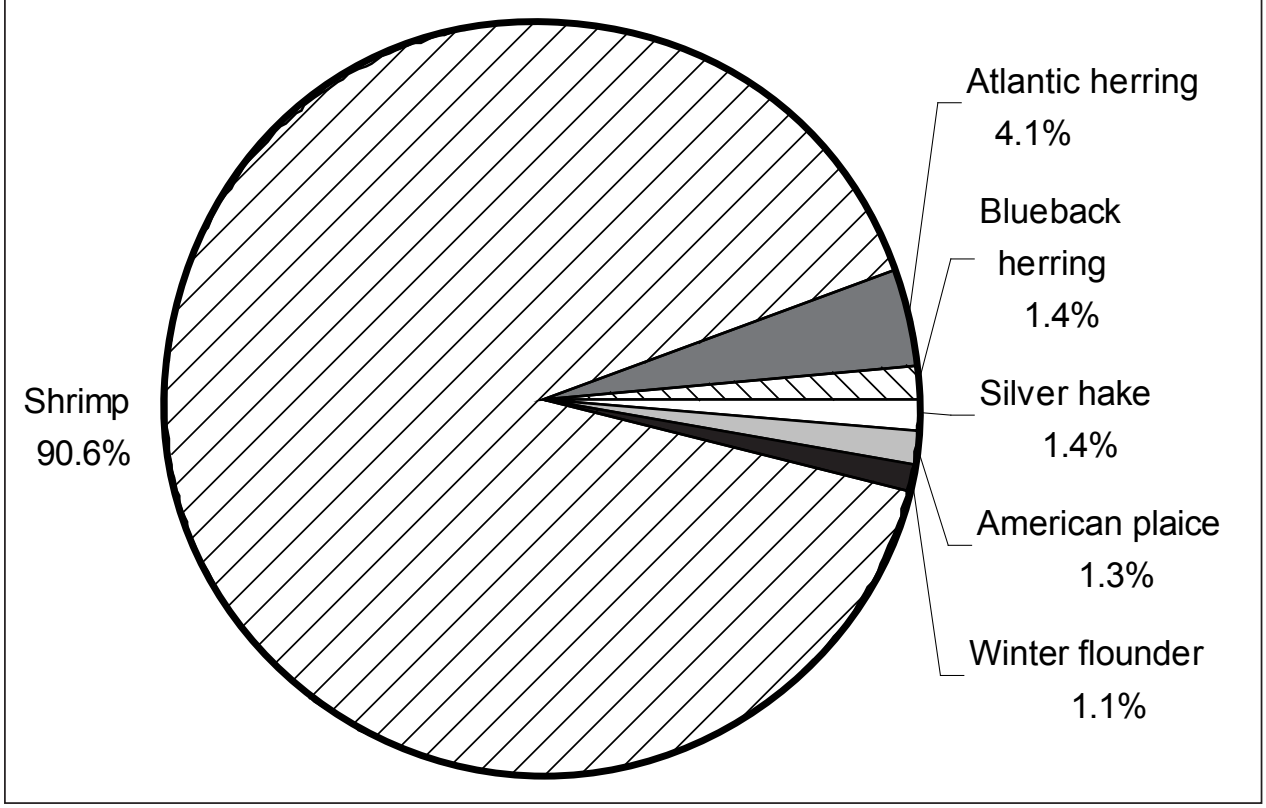

Fig. 5. Total shrimp target species catch and major species of finfish bycatch over 10 tows as percentage of total catch by (A) the topless trawl, and by (B) the commercial trawl. 


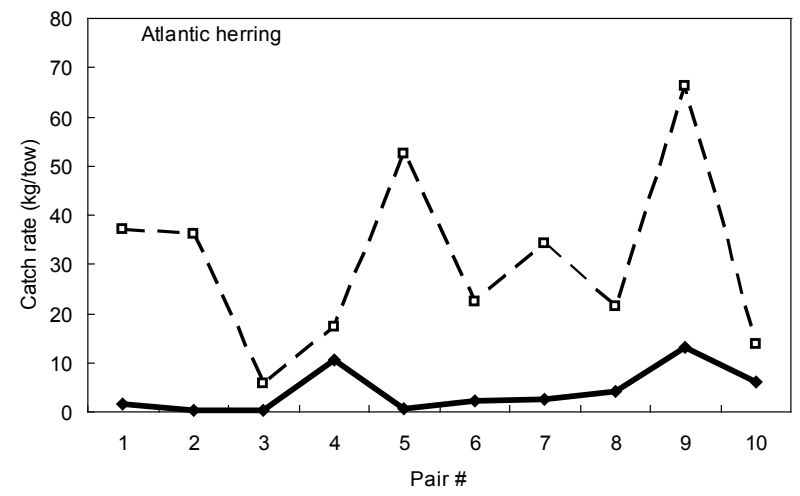

Fig. 6. Bycatch rates ( $\mathrm{kg} / \mathrm{tow})$ of Atlantic herring caught by the topless (- -) and commercial (- - - -) trawls during the 10 pairs of tows.

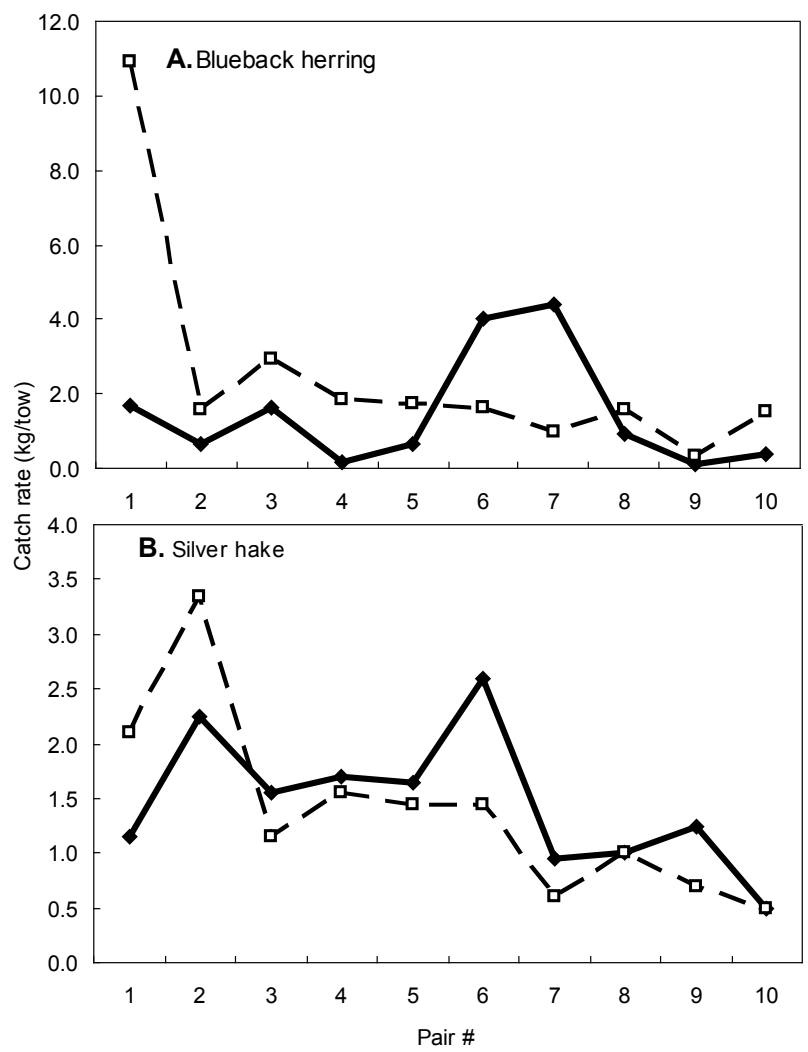

Fig. 7. Bycatch rates (kg/tow) of (A) silver hake and (B) blueback herring caught by the topless (- -) and commercial (- - $\square-$-) trawls during the 10 pairs of tows.

herring than the control gear $(t=2.89$, d.f. $=9, P<0.01)$. The size of Atlantic herring caught was slightly larger in the commercial trawl when analyzed using the twosample K-S test.

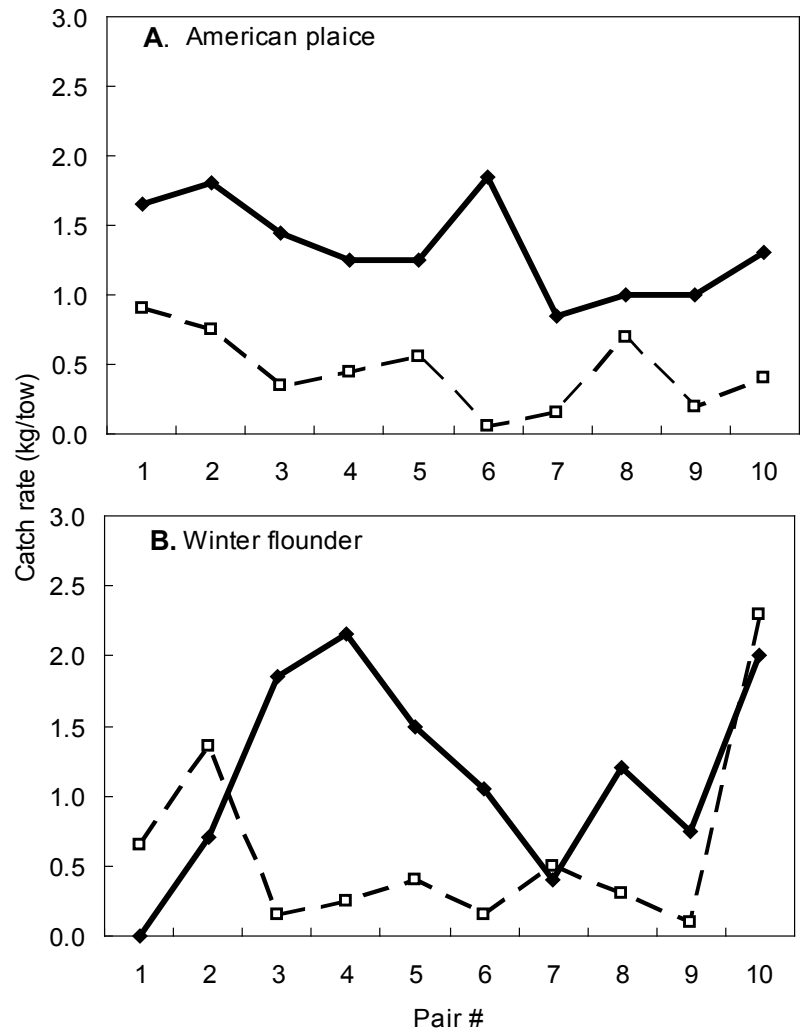

Fig. 8. Bycatch rates (kg/tow) of (A) American plaice, and (B) winter flounder caught by the topless (- - and commercial (- - - - ) trawls, during the 10 pairs off tows.

There were no statistical differences between the control and experimental gears for both blueback herring and silver hake as seen in Fig. $7(P>0.05)$. Though the amount of catch was small for both American plaice and winter flounder, the topless trawl caught statistically more of the two species than the commercial trawl (American plaice: $t=7.26$, d.f. $=9, P<0.001$; winter flounder: $t=1.86$, d.f. $=9, P<0.05$ ) (Fig. 8 ).

\section{Discussion}

The topless trawl performed very well in reducing the amount of bycatch in the Gulf of Maine shrimp fishery. Even though the Nordmore grid was able to exclude the majority of finfish bycatch, small fish and juveniles of large species can still pass through the gap between the bars spaced at $25 \mathrm{~mm}$. In the 10 pairs of comparative tows, the overall bycatch was reduced from $30.5 \%$ to $9.4 \%$ and with a moderate increase in shrimp catch. The primary species reduced was Atlantic herring. The topless feature of the topless trawl provided the opportunity for Atlantic 
herring to swim over the headline and escape capture, virtually eliminating Atlantic herring from shrimp catches. Atlantic herring that escape over the headline may suffer less damage and have higher survival than those that pass through the funnel in front of the grid and bounce off the grid bars before escaping the net.

The increase in shrimp catch may be related to the slightly wider mouth in the topless trawl. In the topless trawl, the upper wingend spread was about $18 \%$ more than the lower wingend spread; in contrast to most commercial shrimp trawls for which upper wingend spread is usually $15 \%$ less than the lower wingend spread (Harold Delouche, Fisheries and Marine Institute, Canada, pers. comm.). Based on measurements of the model at the flume tank and of the full scale net at sea, the mean wingend spread is estimated at $15.35 \mathrm{~m}$ for the topless trawl and $11.48 \mathrm{~m}$ for the commercial trawl respectively. The mean wingend spread was therefore about $33.5 \%$ more in the topless trawl.

There was a slight increase in flounder bycatch in the topless trawl compared to the commercial trawl catches. Though the overall amount of flounder bycatch was small ( $<3 \%$ of total catch), the higher catches were consistent and statistically significant. The increase in flounder bycatch may be partially due to a wider spread of the lower wings, which was about $14.09 \mathrm{~m}$ in the topless trawl compared with $12.28 \mathrm{~m}$ for the commercial trawl. The smaller angle of the lower bridle in the topless trawl $\left(16.7^{\circ}\right)$ may herd flounders more effectively than the larger bridle angle $\left(18.7^{\circ}\right)$ in the commercial trawl. In addition, while the groundgear of both the commercial and topless trawls have the same specifications there could be small differences that may have affected the catch of small flounders and the differences in size distributions of the shrimps. With successful development of the topless concept for reducing pelagic species, it can be reasoned that existing commercial trawls may be modified to become "topless" without changing the rest of the trawl. In this way, bycatch of pelagic species may be reduced without increasing the amount of flounders caught.

Bycatch of pelagic species in shrimp trawls is quite common. In the Gulf of St. Lawrence shrimp fishery, capelin (Mollotus villosus) are caught as bycatch in large quantities (Brothers, MS 2002). There is a potential for use of the topless trawl in this fishery when capelin bycatch is high. Mortality of pelagic species escaping from a trawl codend is quite high (Suuronen et al., 1996). Facilitation of an earlier escape from the net, as is possible in the topless trawl, would improve the survival of escapees (Suuronen, 2005).

\section{Acknowledgments}

This project is funded by the National Marine Fisheries Services Northeast Cooperative Research Partners Program (NCRPP). The project received assistance from Harold DeLouche of the Center for Sustainable Aquatic Resources of the Memorial University of Newfoundland. Sea trials were assisted by the crew of F/V "Ellen Diane".

\section{References}

ARKLEY, K., and G. DUNLIN. MS 2003. Improving the selectivity of towed fishing gears: New prawn trawl designs to avoid capture of unwanted bycatch. SeaFish Report SR542/pp 1430207. Seafish, Hull, UK. 62 p.

BROTHERS, G. MS 2002. Reducing capelin bycatch in the northern Gulf of St. Lawrence shrimp fishery. Project Summary: EACT-16.2002.DFO (FDP 367). Fisheries Diversification Program, Environmental Awareness and Conservation Technology, St. John's, Newfoundland, Canada. 4 p.

CLARK, S.H., S.X. CADRIN, D.F. SCHICK, P.J. DOIDATI, M.P. ARMSTRONG, and D. MCCARRON. 2000. The Gulf of Maine northern shrimp (Pandalus borealis) fishery: A review of record. J. Northw. Atl. Fish. Sci., 27: 193-226.

HE, P., and G. LITTLEFIELD. MS 2006. Design and test of a semi-pelagic shrimp trawl to reduce seabed impact. Northeast Consortium, University of New Hampshire, Durham, NH. UNH-FISH-REP-2006029. 24 p. http://northeastconsortium.org/ProjectFileDownload.pm?report_id=683\&table=project_report

HE, P., D. SCHICK, V. BALZANO, and P. WELLS. MS 2005. Design and test of a kite-assisted shrimp codend to reduce small shrimps and bycatch species. Northeast Consortium, University of New Hampshire, Durham, NH. UNH-FISH-REP-2005-015. 16 p. http://northeastconsortium.org/ProjectFileDownload. pm?report_id $=312 \&$ table $=$ project report

HOWELL, W.H., and R. LANGAN. 1992. Discarding of commercial groundfish species in the Gulf of Maine shrimp fishery. N. Am. J. Fish. Mang., 12: 568-580. doi:10.1577/1548-8675(1992)012<0568: DOCGSI $>2.3 . \mathrm{CO} ; 2$

KENNY, J.F., A.J. BLOTT, and V.E. NULK. MS 1992. Experiments with a Nordmore grate in the Gulf of Maine shrimp fishery. A report of the New England Fishery Management Council to the National Oceanic and Atmospheric Administration. Available from: Northeat Fisheries Science Center, Woods Hole, MA. 
POL, M.V., H.A. CARR, and L.R. RIBAS. MS 2003. Groundfish trawl nets to reduce the catch of Atlantic cod Gadus morhua. Northeast Consortium, University of New Hampshire, Durham, NH. http://www. northeastconsortium.org/ProjectFileDownload. pm?report $\mathrm{id}=92 \&$ table $=$ project report

REVILLA., G. DUNLIN, and R. HOLST. 2006. Selective properties of the cutaway trawl and several other commercial trawls used in the Farne Deeps North Sea Nephrops fishery. Fish. Res. 81: 268-275. doi:10.1016/j.fishres.2006.06.017

SUURONEN, P. 2005. Mortality of fish escaping trawl gears. FAO Fish. Tech. Paper. No. 478: 72 p.

SUURONEN, P., J.A. PEREZ-COMAS, E. LEHTONEN, and V. TSCHERNIJ. 1996. Size-related mortality of herring (Clupea harengus L.) escaping through a rigid sorting grid and trawl codend meshes. ICES J. Mar. Sci.53: 691-700. doi:10.1006/jmsc. 1996.0088

VALDEMARSEN, J.W. MS 2005. Selective shrimp trawl development using behavioral differences between fish and shrimp. In: Report of the ICES/FAO Working Group on Fishing Technology and Fish Behavior (WGFTFB), 18-22 April 2005 Rome, Italy. ICES CM 2005/B:04. p. 205-214. 